\title{
THE INVISIBLE THIRD. \\ THE BASQUE AND CELTIC WORDS FOR 'SWALLOW'
}

\author{
DAVID STIFTER \\ Institut für Sprachwissenschaft, Universität Wien
}

\begin{abstract}
In a keynote address at the XI. Fachtagung der Indogermanischen Gesellschaft, about possible non-Indo-European influence on the Celtic languages, Kim McCone drew attention to the similarity between the Insular Celtic, e.g. OIr fannall, W gwennol, and the Basque, i.e.enara, ain $(h)$ $a r a$, words for 'swallow' (Lat hirundo). McCone reconstructs *waNälä or

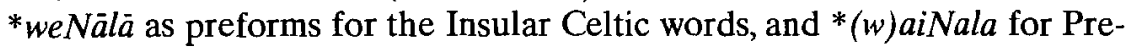
Basque (McCone 2005, 408-9). ${ }^{1}$ This suggestion looks very attractive and suggestive and, if correct, would shed rare light on prehistoric linguistic relationships in Western Europe. In this article, I will examine the equation more closely and add a number of observations.
\end{abstract}

\section{IRISH}

The nominative of the feminine $\bar{a}$-stem OIr fannall is first attested in $\mathrm{Sg}$. $52 \mathrm{~b} 5$. The genitive is attested as faindle ( $L U 6485=T B C 12285)$, the nominative plural as fainnle ${ }^{2}$ (Carney 1971,42 $\$ 8=$ Finn's poem on Mayday from Macgnimartha Finn). The forms with palatalised internal consonant cluster require a front vowel in the second syllable of the pre-form. Since $* i$, which would have caused palatalisation of the preceding consonants after an $a$ of the first syllable (McCone 1996, 116; cf. cainnenn below), is excluded, only ${ }^{*} e$ or ${ }^{*} \bar{e}$ are possible. The Middle and Modern Irish variant ainnel $(l)$ 'swallow', without an initial consonant, must have been abstracted from a lenited form like fainnle and is not evidence for a prehistoric by-form *annilla or the like. As it is first attested in the St Gall glosses, it is possible that $n n$

\footnotetext{
* The research on this article was conducted as part of the 'Old Celtic Language Remains in Austria' project (number P20755), funded by FWF-Fonds zur Förderung der wissenschaftlichen Forschung (details are available at: http://www.fwf.ac.at/ (8 December 2010)). I wish to thank Anders Jørgensen, Kim McCone and Stefan Schumacher, as well as an anonymous reader of Ériu, for their valuable suggestions and support.

1 The symbols $\mathrm{L}, \mathrm{N}, \mathrm{R}$ will be used in this article to represent, on the one hand, the reconstructed fortis resonants of Pre-Basque (see Trask 1997, 139-46), and, on the other hand, the precursors of the unlenited resonants of Insular Celtic. For the purposes of this paper, the exact phonetic reality of these sounds - whether they were geminates or fortes-is irrelevant. What is important, in terms of cross-language contact, is that the Pre-Basque and Celtic sounds can be regarded as structurally equivalent. I use Trask's term 'Pre-Basque' for what could also be called Primitive Basque or Proto-Basque.

2 This is uncertain. The analysis as nom. pl. rests on the emendation of the verb to lengait 'they jump'. The MS actually has lingid, which is singular, but see Carney $(1971,49)$ for a defence of the emendation.
} 
continues Common Celtic * $n d$, but here it must in fact continue geminate/ fortis $* N$. The cluster $* n d$ is excluded because $* a$ would have been raised to $* i$ before a front vowel in the following syllable, cp. ind $<*$ ande (McCone 1996, 78).

Unlenited $l l$ of fannall can go back to earlier geminate/fortis $* L$, but what about single $* l$ ? The development of $* l>$ OIr $l l$ after an unlenited (geminate) ${ }^{*} N$ looks at first sight like an extended application of MacNeill's Law. According to that law in its latest formulation, lenited $r$ and $l$ were strengthened, that is they were delenited, after an unstressed vowel in a syllable that was preceded by $l, r, n$, unlenited $m$ or lenited $b$ (see GOI 89 and especially Stüber 1998, 39-44 for an excellent survey of MacNeill's Law). For the extended version of the law there are a handful of examples: the loans from Latin, connall 'stalk, stubble, aftermath' < Lat cannula 'small, low reed' and cainnell 'candle, light' < Lat candela 'candle', have unlenited $l l$ where Latin has a single $l$ (but cp. also OW cannuill, W cannwyll 'candle' with fortis $l l$ ). The name Sechnall < Lat Secundinus is more complicated, because it requires first a dissimilation of ${ }^{*} n>* l$, before the latter could be strengthened after the strong nasal in the preceding syllable; or ${ }^{*} n$ was first strengthened to $* n n$ and then dissimilated to $l l$. The two examples cainnell and Sechnall might indicate that this particular rule of sonorant strengthening occurred not only after plain * $n n$, but also after ${ }^{*} n d$. If, however, the words entered Irish via a British Celtic language, the assimilation to *nn could already have taken place in the mediating language. A good example of the rule operating on an Irish word (as opposed to a borrowing) is innell (indell) 'arrangement, etc.' < earlier indel, the verbal noun of in'lá 'to yoke; arrange, undertake, etc.'. This example has been cited as proof that MacNeill's Law remained in operation until after the change of OIr $n d>$ $n n$ (GOI 89 and Stüber 1998, 42). It has not been noted that the input form with an unlenited nasal at the beginning of the unstressed syllable does not accord with the usual formulation of the law, which only speaks of lenited sonorants (apart from $m$ ).

A possible further example is furnished by the glossary word finnell 'shield' if, as suggested by DIL F 145.1, it is a variant of finnén 'shield'that is, finnén $>*$ finnen $>*$ finnel (distance dissimilation of the nasal, like in Sechnall) $>$ finnell, although an ad-hoc vowel shortening in the unstressed syllable must be assumed. Bruinnell 'girl, maiden, damsel', attested only in Modern Irish, may belong here if it is derived from bruinne 'breast, bosom, chest' via the addition of a suffix with -l- (thus implicitly LEIA B-104). A similar development is conceivable for grindell (grinnell) "bed of lake or sea, gravel; bedrock, bottom, foundation', but the details are obscure. ${ }^{3}$

${ }^{3}$ It is quite evident that grinnell is in some manner related to OIr grian 'gravel, sand, river bottom', which it sometimes glosses and by which it is sometimes glossed. *Grisano- or *gresano- can be set up as possible preforms for grian and its British cognates W graean, Bret grouan 'gravel'. A further mechanically possible reconstruction, *griiano-, is excluded if grinnell is taken to be related. Grinnell looks like * grisnelo- or * gresnilo-, i.e. like a suffixal enlargement *-elo- or *-ilo- added to the base *gri/esano-, which undergoes unparalleled and early 
Other words, however, are not affected by this strengthening rule, although they conform in structure to the required input: cendail 'heads of decapitated enemies', carnail 'heap of bodies, carnage', cunnail (sic DIL; but cundil in Wb.31c3, which points to original $n d$ ), a laudatory adjective of vague meaning, foindel 'wandering, roving', scandal 'scandal' < Lat scandalum 'id.'. Individual explanations must be sought: scandal could have retained its single $l$ under influence from the Latin word. If carnail is a relatively late loan from Latin carnālis 'fleshly, carnal', its second syllable could be long, in which case it would not be subject to the sound change. Cendail is closely connected to the preceding item; it seems to be composed of cenn 'head' + the morpheme -ail taken from the semantically close carnail. The $a$ is in one instance marked as being long in $L U 9093$. However, carnail could also be related to carn 'heap' (this is a folk etymology undoubtedly developed by the Irish themselves), and note also the rhyme armgail: carnail in the Metrical Dindshenchas 3, 128.16, which suggests a short vowel. ${ }^{4}$ For cundil/cunnail or foindel I can offer no explanation. The latter item is particularly troubling because it is the verbal noun of fo-indlea 'to wander, rove', a compound of the synchronic root *ell (i.e. fo-ind-ell-). DIL does have sporadic examples of foindel with $-l l$, but the spellings with single $-l$ are by far the most common. In the verbal noun of another of its compounds, adall 'visit' (<ad-ell-), the unlenited $l l$ remains as such.

In any case, it is better to speak of a tendency or sporadic change $* l>$ OIr $l l$ in final position rather than of a regular sound law. The more recent loan, tunnall 'cask, barrel' < OFr tonnel 'barrel (ModFr tonneau)', shows that the tendency continued to be active for a long time. It has also been noted that there does not seem to be any rule about whether Latin $l, l l, n$ are represented by single or double $l$ and $n$ in final position in Old Irish (Stüber 1998,43 , citing earlier literature). In view of several native items, however, such as innell or foindel cited above, this development cannot be regarded as being restricted to Latin words. The material could also be analysed so that in absolute auslaut the opposition between lenited and unlenited $l$ was neutralised after unstressed syllables, perhaps across the board, and that the two allophones were then newly distributed according to a principle that has not been uncovered so far.

The quasi-MacNeill effect, if one may so call it, triggered by $n n$ might be expected to operate also on $* n$, the other sound in addition to $* l$ to be affected by MacNeill's Law. Indeed, one example can be found for *nnVn $>$ nnVnn: OIr cainnenn 'onion (?)'5 <*kannina ä, cp. OW + W cennin 'leeks',

syncope to *gri/esn-, so early that the newly arising cluster *-sn- is affected by the Common Celtic assimilation to *-nn-. Another riddle is the relationship of *grisano-/gresano- and *grisnelo-/gresnilo- to MW gro, OCorn grou, MCorn grow, ModBret gro(a), Gaul *grāuā 'gravel', which go together with words in other IE languages derived from ${ }^{*} g^{h} r \bar{e} u, g^{h} r \partial u, g^{h} r \bar{l}^{c}$ to grind, to grate' (IEW 460-2).

4 O Cuív (1980,141-2) remains agnostic about the length of the vowel of the suffix in cendail and carnail.

5 See Kelly (1998: 251-3) for a discussion of the meaning of cainnent. He suggests that the Old Irish word refers to 'onion' rather than to 'garlic' or 'leek(s)', as claimed in DIL C 41.30-1. 
Corn kenin 'onions', Bret kignenn 'garlic', and perhaps the name of the Germanic tribe Canninefates, if this is a hybrid Celtic-Germanic compound 'leek rulers' (thus Schrijver 1995b; sceptical Neumann 2000). The word noinden 'couvade', however, is not so affected.

The upshot of the foregoing discussion is that OIr fannall can tell us nothing about the original fortis-lenis quality of the liquid. The immediate ancestor of the Irish word for 'swallow' can therefore be reconstructed on internal grounds as *uaNelä or *uaNeLä, i.e. with an *e of indeterminate length in the second syllable and with a liquid of indeterminate strength.

\section{BRITISH}

In the British languages, the following forms are attested: MW gwennawl and $\mathrm{pl}$. in placename Aber Gwenoli, ${ }^{6} \mathrm{~W}$ gwennol, OBret guennol $\cdot$ herundo (BN lat. 10290, fol. 25b; Lambert 1982, 186), MBret guennel, ModBret gwennili, Vannetais guignél, guenel, etc. (Trépos 1957, 247), OCorn guennol - hirundo (Voc. Corn. 514). The Old South-West British forms stand for [gwennöl]. It is noteworthy that in Middle Breton the word did not undergo assimilation ${ }^{*} e . . . e u>{ }^{*} e u \ldots e u$ (Schrijver 1995, 210-11), i.e. ${ }^{\dagger}$ [gwønnøl] (pers. comm. Stefan Schumacher). The rounding of the $e$ in the first syllable may have been prevented by a dissimilatory effect of the preceding $w$. In Modern Breton, the expected reflex was analogically replaced by a form that has been abstracted from a double plural formation gwennilied (Trépos 1957, 247). ${ }^{7}$

By internal reconstruction, one arrives for Proto-British at *ueNàlā. Even though in the attested British languages $\mathrm{CC}{ }^{*} n n$ and ${ }^{*} n d$ had fallen together in ${ }^{*} N,{ }^{*} n d$ is excluded in this case because of the different treatment of ${ }^{*} e$ in the two environments. Before $* n+$ consonant $\mathrm{CC} * e$ was raised to ${ }^{*} l$, which merged with $* i$ and surfaces as $y$ in Welsh, whereas before $*^{*} n$ the vowel remains * $e$ (Schrijver 1995, 39 and 455-6). CC * $n n$ usually continues PreCeltic *sn, but might conceivably also reflect $* n$ or $* N$ in loanwords. The $e$ of *ueNála cannot be due to final $a$-affection, since that rule operated only in the syllable immediately before a final $a$. Although it is clear that *ueNäla must be somehow related to the Irish word, it is not possible to derive both words from a unitary pre-form, without invoking irregular developments.

The most recent etymology, aside from that of McCone 2005, was proposed by Lockwood 2002, who offered an IE pre-form. As the ancestor for W gwennol he postulated *uindàla croisée involving W gwyn/gwen < *uindo- 'white' and Proto-Celtic *uandālā

${ }^{6}$ The burial place of Pryderi. The placename is attested in stanza 7 of Englynion y Beddau (see Jarman 1982, 36; pers. comm. Stefan Schumacher).

7 As an example of a modern dialectal form that directly continues the inherited word, Anders Jørgensen has brought to my attention the Île-de-Groix form [ḑynael], which fairly clearly comes from * gwennel $<{ }^{*}$ gwennol $<*$ gwennol. Ile-de-Groix [ae] is the development of long, stressed * $\varepsilon$, usually from OBret *ai or unrounded * $\alpha$. 
'swallow', set up on the basis of Irish fannall. He then analysed *uandālā as containing a 'Pr.Celt. root *wand-' for 'wand; rod > fork'; the name of the bird is accordingly thought to mean 'little fork', deriving from the swallow's conspicuous tail. Lockwood's proposal, however, suffers from several weaknesses. Gwennol cannot directly continue *uindāla , because the $*_{i} i$ would not have been lowered by final $a$-affection (see above); * uindāla would have resulted in $\mathrm{W}^{\dagger}$ gwynnol. At most, it could be assumed that speakers of British Celtic created a folk etymology by crossing the reflex of *uandāla with the feminine adjective gwen 'white' after the operation of final $a$-affection. The ancestor of fannall cannot have contained $\bar{a}$ in the second syllable, as already demonstrated above. Germ. *wand-, which Lockwood cites as a parallel for an identical Proto-Celtic root, reflects the $o$-grade of the verbal root *wend- 'to wind, plait, twist, turn' $<$ PIE *uend ${ }^{h}$. This, of course, should surface as ${ }^{\dagger}$ uond-in Celtic. While it is true that in Gaulish and British *uo would have become *ua in a subsequent development (Schrijver 1995, 116-130), nothing of that sort happened in Irish; the OIr word for 'swallow' should therefore surface as ${ }^{\dagger}$ fonnall. Lockwood provides no explanation for the unusual suffix *-āla. Finally, the semantic leap from 'to wind' to 'fork' is a rather large one and, although he manages to adduce a semantic parallel from Russian (vila 'fork' beside vit' 'to wind, turn, plait'), there is no parallel for the use of a nominal derivative of *uend ${ }^{h}$ in the meaning 'fork'. Lockwood's attempt to trace the etymology must therefore be regarded as unsuccessful.

On the basis of the British forms, Matasović (2009, 391-2) sets up ProtoCeltic *wesnāla . He derives this from the weak stem of the PIE heteroclitic noun *uesr/n- 'spring', via the addition of a Common Celtic adjectival suffix ${ }^{*}-\bar{a} l o / \bar{a}$-. The swallow is thought to be the 'spring-bird', the 'messenger of spring'. While Matasović's idea is semantically very attractive, there are several formal obstacles facing it. The vocalism of the first syllable of OIr fannall is explained by reference to an assimilation to the $* \bar{a}$ of the following syllable (similar to Joseph's Rule ${ }^{8}$ ). However, as we have seen above, the Irish word originally contained $* e$ or $* \bar{e}$ in the second syllable; therefore no assimilation can have taken place. Furthermore, the evidence for the suffix ${ }^{*}-\bar{a} l o / \bar{a}-$ is very thin. The adjectival suffix $-o l$ in Welsh is thought to continue Latin -âlis, and the Irish words that he adduces in support (i.e. mebul 'shame' and búal 'water') do not contain *-ālà-, but rather *-lā-. These objections render Matasović's proposal implausible.

\section{Gallo-Romance}

The Irish and British words for 'swallow' are not the whole story. There is another possible, but only indirectly accessible, Celtic word that could 
be part of this grouping. The Gallo-Romance word for the 'lapwing' (zool. Vanellus vanellus), represented by French vanneau, continues a Vulgar Latin word *uannellus, which is not attested as such. FEW 14, 157-62 contains a full selection of dialectal variants in Gallo-Romance.

Two explanations have been suggested for *uannellus. One strategy, the majority view in Romance lexicography (see below), is to look for an etymology internal to Latin. This was found in Lat uannus 'winnowing fan', enlarged by the diminutive suffix -ellus. The lapwing is thought to have been named after its characteristic wing beat, which is reminiscent of the movement or sound of a winnowing fan in action. The pinion feathers are called vanni in Italian and vanneaux in dialectal French (Brüch 1932,355). A minority position favours a loan from Gaulish, on account of the formal similarity with the Insular Celtic words, which did not go unnoticed, and because of the geographically restricted distribution ${ }^{9}$ (VGK I, 174; Brüch 1932; Meyer-Lübke 1935, 9140). This view was generally rejected, although the motivation for doing so was based on a wrong evaluation of the facts: from OIr fannall, Common Celtic and Gaulish forms like *uannallos, *uannālos, uel sim. were mechanically reconstructed (Diez 1887, 337; Spitzer 1934; Wagner 1954, 254-5, FEW 14, 161, Campanile 1974, 55). These forms, in turn, were declared to be unsuitable for explaining the Romance word because they displayed no strict sound correspondence. However, if one takes into consideration the fact that $* e$ is actually needed for the second syllable of the pre-form of fannall, and that *uaNeLa is one of the possible reconstructions, the Celtic and Romance pre-forms emerge as identical, notwithstanding the different gender.

While it is true that the lapwing's characteristic flap may have been a factor in imparting a meaning to the bird's name in folk etymology, this need not have been the original motive for naming the bird: the folk etymology could well have applied after the word entered Vulgar Latin. In this case, the folk etymology can supply a reason for the transference of the name from the swallow to the lapwing. The semantic divergence between reconstructed Gaulish *uannellälos 'swallow' and Gallo-Romance *uannellus 'lapwing' is not a decisive obstacle. Both birds are comparatively small, ${ }^{10}$ and both birds share a black-and-white coloration at least on a portion of their plumage. The transference of names for animals or plants is not an uncommon phenomenon and as such does not render the explanation unlikely.

With the proviso that the word may have changed its gender in the process of borrowing, Gaulish *uannellälos can be set up as the source of borrowing. This, in turn, can only continue pre-Gaulish *uaNeLä/os.

9 According to Brüch 1932 and FEW 14, 161-2, the word originated in Gallo-Romance, from which the Italian cognates were borrowed.

${ }^{10}$ The lapwing being rather larger than the swallow; Bruich $(1932,356)$ suggests that the lapwing could have been regarded as a large swallow. 


\section{Common Celtic}

If we try to combine the Celtic material into a single reconstruction, the first problem to be encountered concerns the forms on which the reconstruction is to be based. If one looks at the Insular Celtic words alone, the conclusion is almost inevitable that one is dealing with formally incompatible words that were separately borrowed from external sources that are not identical (thus McCone 2005, 409). However, when the Gaulish evidence is also drawn upon, the ease with which the Irish and Gaulish words can be so effortlessly combined in *uaNeLälos is in itself an argument for postulating a unitary Common Celtic word for the 'swallow'.

The question that then arises is why did the word undergo metathesis of the vowels and lenition in the second fortis sonorant in British? One possible explanation is as follows: **gwannell, the expected outcome of $*_{\text {L }} a \mathrm{NeL} \bar{a}$ in Welsh, would have looked like a derivative in -ell from the verbal stem gwan- 'to wound'. The suffix -ell is a loan from Lat -ellus/a/um and is common for instruments and tools, and objects in general (Zimmer 2000, $355-62$ ), and as such, the meaning of **gwannell would have been analysable approximately as 'wounding implement'. This may not have been considered as representing an appropriate image for a harmless bird like the swallow. The metathesis of the vowels created an allusion to gwen 'white (fem.)', one of the conspicuous colours of the bird. The new 'suffixoid' *-all may have come under pressure from the productive adjectival suffix *-a $l$ $<$ Lat $*$-älis. ${ }^{11}$

The alternative to this scenario is that a hypothetical Irish pre-form, perhaps similar to the British form, was remodelled under influence from Vulgar Latin *uannellus (of whatever origin). This is unlikely for two reasons: if the Vulgar Latin word already meant 'lapwing' there would have been no discernible reason for it to exert influence on a word for 'swallow'. More importantly, however, the word *uannellus does not appear in the two main sources of Hibernian Latin, i.e. the classical language and its British variant. It is unwise, therefore, to posit influence from a form that probably did not exist.

Thus, the Celtic evidence, if we admit the Gallo-Romance word to the equation, favours a Common Celtic reconstruction * ra $_{a} \mathrm{Ne} L \bar{a} / o s$. Structurally, the two fortis sonorants are striking. These cannot have been inherited from Indo-European, which lacks those sounds. $C^{*} N$ and ${ }^{*} L$ usually continue Pre-Celtic * $s n$ and ${ }^{*} s l$, but neither of these is a likely source of fortis sonorants in the present case. There is no etymological analysis within Celtic or Indo-European that suggests itself for *uaNeLä/os or, for that matter, for

11 The word for 'swallow' underwent irregular, unpredictable transformations in other languages as well: Lat hirundo 'swallow' is reflected by such diverse forms as Portuguese andorinha, Galician andoriña, Spanish arandela, golondrina, Catalan oreneta, oronella, Occitan randoleta, Old French aronde, Italian rondine, Ladin rondola, Romansh randulina, Romanian rândunică (information taken from Grzegor Jagodziński's website: http:/grzegorj.private.pl/ lingw/nieregl.html (2 November 2010)). 
* uasneslä/os. There remain only two alternatives: either the word is a lexical creation of Common Celtic age, or it is a loan from another language, non-IE in all likelihood. In what follows, I will investigate the second of these alternatives.

From the foregoing discussion it will have become apparent that neither *uaNeLälos nor *ueNaLälos as loans from some other language can add anything to the understanding of the somewhat complicated development of *ann or *enn in Celtic. It has been observed by Schrijver $(1995,39$ and 455-6) and McCone $(1996,46)$ that Proto-Celtic * $a$ and ${ }^{*} e$ had different reflexes before ${ }^{*} n n<{ }^{*} s n$ and before ${ }^{*} n C$ or ${ }^{*} n n<* n d n$. While in the latter contexts the vowels were raised to ${ }^{*} \alpha$ and ${ }^{*} l$, no raising occurred before earlier *sn. Neither *uaNeLälos nor *ueNaLälos shows raising, but this is irrelevant to the question at hand. What is important is that the borrowing occurred after the Celtic change $*_{s n}>{ }^{*} n n$ had taken place, and that the borrowed sequence *ann (or *enn) was associated with the reflex of earlier *asn $\left({ }^{*} e s n\right)$.

\section{BASQUE}

The Basque dialects display a wide range of variant words for the 'swallow', the standard variants of which are enara and ainhara.$^{12}$ Most of these can be traced to two Pre-Basque variants *eNala/eLana (Michelena 1961,326) or *aiNala/aiLana, with the diphthong ai instead of $e$ in initial position (thus Trask 1997, 139). ${ }^{13}$ With the application of a number of Basque sound laws, the basic dialectal variants can be derived from these without difficulty. ${ }^{14}$

The pair *eNala/eLana (or *aiNala/aiLana) is highly unusual, in that it shows metathesis of both consonants and their articulatory quality, viz.

12 Both are used as headwords in Trask 2008. Trask cites the following attested dialectal forms $(B=$ Bizkaian, $G=$ Gipuzkoan, $H N=$ High Navarrese, $A=$ Aezkoan, $S=$ Salazarese, $R=$ Roncalese, $\mathrm{L}=$ Lapurdian, $\mathrm{LN}=$ Low Navarrese, $Z=$ Zuberoan; Sout = the extinct and poorly attested Southern dialect of Alava): 'enara (B Sout G HN (L\}) (1562), enada (B G HN L [S.P.]) (1660), enere (HN), ainhara (L Z) (1859), einhara (L), ainhera (LN), inhara (L LN) (1657), añhá(r)a (Z), añhé(r)a (Z), añ (h)era $(\mathrm{LN})$, inhade (L), ernara $(\mathrm{B})$, inara $(\mathrm{HN})$, iñara (HN), iñare ( $\{\mathrm{HN}\} \mathrm{A})$, iñar (R S), aiñari $(\mathrm{S})$, aiñara $(\mathrm{LN})$, añari $(\mathrm{R}\{\mathrm{S}\})$, alñari $(\mathrm{R})$, kiñuri $(\mathrm{S})$, kinuri (S), mañari (R), enabera (B HN), egabera (B HN), egabela (B HN); elae (old B) (1596), elai (B) (1745, ca. 1808), alae (B), alai (B G) n. 'swallow' (zool.) (Hirundo rustica) (in R and elsewhere, 'swift' (zool.) (Apus apus))' (2008,170).

${ }^{13} \mathrm{I}$ am in no position to judge whether the forms with * $e$ - or those with *ai-account better for the diverse Basque forms; Trask does not elaborate on this point.

14 Rule 1: Pre-Basque lenis * $n$ is lost between two vowels (Trask 1997, 139-40; 2008, 25).

Rule 22: Lenis * $l$ between vowels becomes $r$ (Trask 1997, 142-4;2008, 29).

Rule 23: The contrast between lenis and fortis $/ L$ and $n / N$ thus having been eradicated in the language, as a consequence fortis $* N$ and ${ }^{*} L$ merged with simple, lenis $n$ and $l$ that had survived in non-intervocalic position (Trask 1997, 139 and 143;2008,29).

Rule 30: In some dialects, ${ }^{*} n$ after ${ }^{*} i$ is automatically palatalised to $\tilde{n}$ (Trask 1997, 146; $2008,30)$.

Rule 35.4: Two as having come into contact after the loss of ${ }^{*} n$ developed into *ae (Trask 2008, 31).

With the addition of a few sporadic, irregular, but trivial secondary remodellings, most forms can be explained in this manner. 
fortis or lenis articulation, a binary opposition that is fundamental to the phonemic system of Pre-Basque (Trask 1997, 126; 2008, 14). From the odd behaviour of the 'swallow'-word, whereby the fortis articulation is connected with the first and the lenis articulation with the second position, irrespective of which sound is involved, it may not seem rash to speculate that at an even earlier period than the reconstructable Pre-Basque language of c. 2000 years ago there originally obtained a situation where fortis sonorants occupied both positions, i.e. **eNaLa/eLaNa or **aiNaLa/*aiLaNa, and that this was then lost by dissimilation in the second slot.

The only other trisyllabic Basque word with two fortis sonorants in consecutive syllables I could find is arrano 'eagle' < Pre-Basque *aRaNo. This word's relationship to PIE * $h_{2}$ eron- 'eagle' (Hitt. häran-, PGerm. *aran-) is suggestive, but the conjecture is not provable. The exceptional phonotactic structure may be iconic in the name of this majestic bird. The structure (C) $\mathrm{VC}_{[+ \text {fort }]} \mathrm{VC}_{[+ \text {fort }]} \mathrm{V}$ is not found in trisyllabic stems, although the basis for this observation is admittedly very slim, and trisyllabic stems are altogether rare (see Trask 2008, 18, 391-5 and 398-9). Among disyllabic stems, however, the structure $(\mathrm{C}) \mathrm{VC}_{[+ \text {fort }]} \mathrm{VC}_{[+ \text {fort }]}$ is not uncommon. I regard the fact that we find this double metathesis in 'swallow' as an indication that the word originally possessed a structure that was unusual or ill-suited for the phonological system of Pre-Basque. As in Celtic, structural anomalies suggest a loan from another language. Furthermore, there is no linguistic material that would allow a morphological-etymological analysis of the word within Basque, although in the case of an isolated and late attested language like Basque this argument does not carry much weight.

\section{Evaluation}

As originally pointed out by McCone, the Celtic and Basque words for 'swallow' are so conspicuously similar that one is almost compelled to consider some sort of connection between them. Six scenarios are conceivable:

1. the similarities are due to chance or onomatopoeia;

2. a loan from Basque into Celtic;

3. a loan from a Celtic language into Basque;

4. a loan from a third language into both Basque and Celtic; and

5. a loan from a third language into Basque and then from Basque into Celtic, or with inverted roles for Celtic and Basque $=6$.

Scenario 1, chance similarity or onomatopoeia, is ruled out: the reconstructable items are relatively complex and contain marked phonemes; and neither CC *uaNeLälos nor Pre-Basque * eNala'eLana or *aiNala/aiLana are imitative of the swallow's call or otherwise suggestive of an iconic formation. Scenario 2, according to which the word would have originated in Basque, and scenario 5 are excluded because Pre-Basque had no bilabial glide * $u$ (Trask 1997, 155); nor are there any indications that it ever possessed that 
sound even in its more remote prehistory. In items like *haur 'child', *laur 'four' or *euri 'rain', the second element of the diphthong is phonologically an allophone of the vowel $u$, not the positionally restricted occurrence of a phoneme ${ }^{*} u$. The presence of the initial ${ }^{*} u$ in the Celtic words would be entirely inexplicable under this scenario. Moreoever, as argued above, the unusual metathesis in the allomorphs of the Basque word points to a loan from another source in to Basque. Scenario 3, whereby the word would have originated in Celtic, is excluded because no reasonable Celtic etymology can be established; that is to say, no etymology that would explain the word by means of inherited Indo-European and/or newly acquired lexical and derivational morphemes. Scenario 6 cannot be wholly excluded, but requires additional assumptions: since in that case *uaNeLä/os would have been the input form, the initial * $u$ would have been replaced in Basque by zero (see below for further discussion) and the order and the quality of the reconstructed vowels would have been heavily altered, in order to arrive at Pre-Basque *eNala/eLana or *aiNala/aiLana. Finally, there remains scenario 4 . This scenario means hedging one's bets, because methodically speaking it cannot be falsified. Any irregular correspondence in the attested forms can be projected onto hypothetical, but undisprovable, properties of the unattested source language. Critical as this may sound, it is nevertheless the strategy adopted here, because an internal explanation could not be found for Celtic in the first place, and an external explanation seems probable for Basque.

Most of what can be said about the properties of the proto-form has already been touched upon in the preceding sections: the word contained a fortis ${ }^{*} N$ and quite probably a fortis ${ }^{*} L$, or, alternatively, geminate ${ }^{*} n n$ and ${ }^{*} l l$. The syllable structure is simply ${ }^{*} \mathrm{CV}$, without consonant clusters. Initially, the word contained a single initial $* u$. It must have been borrowed into Basque so early that either Basque lost the initial consonant before its earliest recoverable stages (cp. Trask 1997, 180-3), or the sound was replaced by zero, not by ${ }^{*} b$ as in the case of loans from the Roman period or later (L3.1. in Trask 2008, 52). The vowels are elusive. The word apparently contained the central vowel * $a$ and another vowel with a front feature, but the order of these is unrecoverable. Basque (and perhaps British) supports the order ${ }^{*} e / a i \ldots a$, whereas Irish and Gallo-Latin support ${ }^{*} a \ldots e$. It is possible that the word ended in $* a$, or at least in a vowel. The attested forms do not point to a length opposition between the vowels (the ${ }^{*} \dot{a}$ of the British forms may be due to analogy, as argued above; the final ${ }^{*} a$ of the Insular Celtic words is, of course, morphologically conditioned). Provisionally, the following reconstructions can be set up: *uai/eNaLa or *uaNai/eLa. It would involve too much speculation to reconstruct *uaiNaiLa with dissimilatory adaptations of the vowels in the individual languages. There remains the task of putting the reconstruction into a wider context.

Schrijver (1997) identified a number of words in Western European languages which, by virtue of irregular sound correspondences and of unusual morphophonemic behaviour, he derived from a common, unknown 
substratum language somewhere in the West of Europe. He highlighted two features of primary importance for this substratum:

1. A sound, provisionally reconstructed as [aə], that could be variously rendered by the sounds * $a$ or $* a i$ in loans from this language.

2. An optional determinative (?) prefix * $a$-, the addition of which triggered reduction of the vocalism in the following word.

Because a significant subgroup of the words identified by Schrijver denotes birds, in a later publication he labelled this linguistic stratum 'language of the bird names' (Schrijver 2001, 419). ${ }^{15}$ Given that the 'swallow' belongs to this semantic field, it seems obvious to ask whether the present reconstruction can also be referred to Schrijver's 'Avidic' language. If we adopt this assumption, the following observations can be made:

While the second feature of Avidic, the prefix * $a$ - and the concomitant ablaut-like phenomenon (Schrijver 1997, 313), is of no relevance to the present item, it is remarkable that there may be some kind of allophony involving *ai (possibly in Basque) and ${ }^{*} a$, which is reminiscent of the way Avd *aว is treated in IE languages. There is, however, an important difference between the word for 'swallow' and Schrijver's items. Schrijver suggested that Avd *az was borrowed into British as * $a$, but into Irish as *ai $(1997,305-6)$. This implies that borrowing into the Insular Celtic languages of the words identified by Schrijver took place at a relatively late date, when Proto-Irish and Proto-British were clearly separate languages. The foregoing discussion, however, amounts to the hypothesis that the word for 'swallow' was already borrowed into Common Celtic. If 'swallow' is indeed a loan from Avidic, it follows that there must have been several waves of loans from the Avidic substratum into Celtic languages at different periods, with different treatments of the foreign phoneme *ao.

On the basis of his etymologies, Schrijver identified three Avd sounds alien to the early IE languages of Western Europe: *aว, ${ }^{*} x$, and $* \delta$ (1997, 313). ${ }^{16}$ For the item under discussion here, the latter two are of no relevance; the possible relevance of the first sound has already been discussed. *u, the initial sound of the 'swallow'-word, features in Avidic as a sound permitted at least in word-internal or word-final position (*sprazw 'starling, jackdaw', *glaaw 'clover'). The words reconstructed by Schrijver do not exhibit a particular preference for fortis/geminate sonorants, even though one item, *s $(V)$ mmarr 'clover', has to be reconstructed with * $m m$. Many of Schrijver's Avidic lexemes begin with quite complex consonant clusters that are reminiscent of the phonotactics of Indo-European, e.g. *kraxar 'heron', *spraaw 'starling, jackdaw', *glaaw 'clover'; some of the reconstructions contain $m$, e.g. **s(V)mmaar 'clover' and *mesal-/a-m(V)sl- 'blackbird'. Since

15 In order to avoid the cumbersome original name, this language is hereafter called 'Avidic', abbreviated 'Avd'.

16 Incidentally, the presence of two fricatives in a lost language of Western Europe is of interest regarding a possible substratum origin of lenition in Celtic languages. 
no historic variant of Basque permitted initial consonant clusters, and since pre-Basque lacked the sound * $m$, Avidic cannot be Pre-Basque.

In conclusion, it can be said that the Basque and Celtic words for 'swallow' (including perhaps the Gaulish word implied by the Gallo-Romance word for 'lapwing') are etymologically connected by being ultimately borrowed from a provisionally reconstructed *uai/eNaLa or *uaNai/eLa swallow'. The most that can be said is that the word probably belonged to an otherwise unknown substratum language in Western Europe. This third language is 'invisible', in the sense that it has come down to us neither as a living language, nor as a corpus language, not even in fragmentarily attested form. There is not even a reference to it by ancient authors, or at least none that we can identify. And yet this invisible language has left faint traces. If the reconstructions are not mere phantoms, these traces can be found in occasional loan words, loans into better attested European languages that sometimes stand out because of some phonological or morphological quirk. Everything beyond this general characterisation becomes very speculative. In principle, there is no formal obstacle to referring the present etymon to Schrijver's 'language of the bird names', a hypothetical substratum language in Western Europe of the type mentioned above; although there is no compelling positive evidence for doing so either. Perhaps we will be able to make more progress on this question in the future, when more items are identified.

\section{AbBreviation}

FEW 14 Französisches Etymologisches Wörterbuch. Eine darstellung des galloromanischen sprachschatzes. Verfasst von Walther v. Wartburg. 14. Band U-Z. Basel 1961.

\section{REFERENCES}

Brüch, J., 1932: 'Frz. vanneau "Kiebitz", Zeitschrift für französische Sprache und Literatur 56, 355-8.

Campanile, E., 1974: Profilo etimologico del cornico antico. Biblioteca dell'Italia dialettale e di studi e saggi linguistici 7. Pisa.

Carney, J, 1971: 'Three Old Irish accentual poems', Eriu 22, 23-80.

Diez, F.Ch., 1887: Etymologisches Wörterbuch der romanischen Sprachen. Fünfte Ausgabe. Bonn.

Jarman, A.O.H., 1982: Llyfr Du Caerfyrddin. Gyda rhagymadrodd, nodiadau testunol a geirfa. Caerdydd.

Joseph, L., 1982: 'The treatment of *CRH-and the origin of CaRa-in Celtic', Eriu 33, 31-57.

Kelly, F. 1998: Early Irish farming. A study based mainly on the law-texts of the 7 th and 8 th centuries $A D$. Early Irish Law Series 4. Dublin. 
Lambert, P.-Y., 1982: 'Les gloses du manuscrit BN lat. 10290', ÉC 19, 173-213.

Lockwood, W.B., 2002: 'Welsh Gwennol, etc.: an etymology', Studia Celtica 36, 148.

Matasović, R., 2009: Etymological dictionary of Proto-Celtic. Leiden-Boston. McCone, K., 1996: Towards a relative chronology of ancient and medieval Celtic sound change. Maynooth Studies in Celtic Linguistics 1. Maynooth.

McCone, K., 2005: 'Mögliche nicht-indogermanische Elemente in den keltischen Sprachen und einige frühe Entlehnungen aus indogermanischen Nachbarsprachen', in G. Meiser and O. Hackstein (eds.), Sprachkontakt und Sprachwandel. Akten der XI. Fachtagung der Indogermanischen Gesellschaft, 17.-23. September 2000, Halle an der Saale, 395-435. Wiesbaden.

Meyer-Lübke, W., 1935: Romanisches etymologisches Wörterbuch. Heidelberg.

Michelena, L., 1961: Fonética histórica vasca. San Sebastián.

Neumann, G., 2000: 'Kananefaten. Der Name', in H. Beck et al. (eds), Reallexikon der germanischen Altertumskunde. Begründet von Johannes Hoops. Zweite Auflage. Band 16. Jadwingen - Kleidung, 217-19. Berlin.

Ó Cuív, B., 1980: 'The verbal noun ending -áil and related forms', Celtica 13, 125-45.

Schrijver, P., 1995: Studies in British Celtic historical phonology. Leiden Studies in Indo-European 5. Amsterdam-Atlanta.

Schrijver, P., 1995b: 'De etymologie van de naam van de Cannenefaten', Amsterdamer Beiträge zur älteren Germanistik 41, 13-22.

Schrijver, P., 1997: 'Animal, vegetable and mineral: some Western European substratum words', in A. Lubotsky (ed.), Sound law and analogy. Papers in honor of Robert S.P. Beekes on the occasion of his 60th birthday, 293316. Leiden Studies in Indo-European 9. Amsterdam.

Schrijver, P., 2001: 'Lost languages in northern Europe', in Christian Carpelan et al. (eds.), Early contacts between Uralic and Indo-European: linguistic and archaeological considerations. Papers presented at an international symposium held at the Tvärminne Research Station of the University of Helsinki. 8-10 January, 1999, 417-25. Suomalais-Ugrilaisen Seuran Toimituksia 242. Helsinki.

Spitzer, L., 1934: 'Frz. vanneau "Kiebitz"', Zeitschrift für französische Sprache und Literatur 58, 316-17.

Stuiber, K., 1998: The historical morphology of n-stems in Celtic. Maynooth Studies in Celtic Linguistics 3. Maynooth.

Trask, R.L., 1997: The history of Basque. London-New York.

Trask, R.L., 2008: Etymological dictionary of Basque. Edited for web publication by Max W. Wheeler. Sussex.

Trépos, P., 1957: Le pluriel breton. Brest.

Wagner, M.L., 1954: 'Ueber einige iberoromanische Raubvogelnamen', in Estudios dedicados a D. Ramón Menéndez Pidal 4, 239-64.

Zimmer, S., 2000: Studies in Welsh word-formation. Dublin. 